\title{
Stratifying primary Sjögren's syndrome: killers in the balance?
}

\author{
Simon J. Bowman ${ }^{1,2^{*}}$ and Benjamin A. Fisher ${ }^{1,2}$ \\ See related research by Seror et al., http://www.arthritis-research.com/content/17/1/241
}

\begin{abstract}
The article by Seror et al. in Arthritis Research \& Therapy reports data from the 15 French patients in the open-label BELISS (Efficacy and Safety of Belimumab in Subjects With Primary Sjögren's Syndrome, NCT01160666) study of belimumab in primary Sjögren's syndrome. The study identifies that higher baseline levels of natural killer cells in the peripheral blood and salivary glands are associated with non-response to belimumab therapy. Although caution is required given the open-label nature of the trial, this study adds to data already suggesting a role for natural killer cells in primary Sjögren's syndrome and, importantly, indicates a need for therapeutic stratification.
\end{abstract}

Primary Sjögren's syndrome (pSS) is characterised by lymphocytic infiltration of the salivary and lacrimal glands leading to symptoms of dryness and systemic manifestations in 30-40\% of patients. B-lymphocyte hyperactivity is considered a key feature of pathogenesis and results in B-cell lymphomas in $5 \%$ of patients. Levels of the B-cell activating factor (BAFF) (also known as B-lymphocyte stimulator) are associated with markers of B-cell hyperactivity in pSS, and a mouse model overexpressing BAFF has features of pSS and increased lymphoma risk. BAFF therefore offers a promising therapeutic target.

The article by Seror et al. [1] , in Arthritis Research \& Therapy makes an important observation relevant to treatment and pathogenesis of pSS, based on an analysis of samples from the BELISS (Efficacy and Safety of

\footnotetext{
* Correspondence: simon.bowman@uhb.nhs.uk
${ }^{1}$ Rheumatology Research Group, University of Birmingham, Edgbaston,

* Correspondence: simon.bowman@uhb.nhs.uk
${ }^{1}$ Rheumatology Research Group, University of Birmingham, Edgbaston, Birmingham B15 2WD, UK 2Department of Rheumatology, University Hospitals Birmingham NHS Trust, Queen Elizabeth Hospital Birmingham, Mindelsohn Way, Edgbaston, Birmingham B15 2TH, UK
}

(c) 2015 Bowman and Fisher. Open Access This article is distributed under the terms of the Creative Commons Attribution 4.0 International License (http://creativecommons.org/licenses/by/4.0/, which permits unrestricted use, distribution, and reproduction in any medium, provided you give appropriate credit to the original author(s) and the source, provide a link to the Creative Commons license, and indicate if changes were made. The Creative Commons Public Domain Dedication waiver (http://creativecommons.org/publicdomain/zero/1.0/) applies to the data made available in this article, unless otherwise stated.

Belimumab in Subjects With Primary Sjögren's Syndrome, NCT01160666) study. BELISS included 15 patients from France and 15 from Italy. Patients received belimumab, a monoclonal antibody against BAFF, at 0,2 and 4 weeks and then every 4 weeks for up to a year. Clinical data have already been published [2], but in the French cohort studied here, an improvement in the EULAR (European League Against Rheumatism) Sjögren's Syndrome Disease Activity Index (ESSDAI) was observed in 6 out of the 15 patients.

We strongly welcome the biologic era in pSS. Although pSS is not associated with increased mortality (except for the small number of patients with aggressive forms of lymphoma), it is associated with significant and disabling symptoms and little evidence that conventional immunosuppressant therapy is effective. In terms of the clinical data from BELISS, there is an obligatory note of caution: a fully powered double-blind randomized controlled trial (RCT) of infliximab in pSS failed to demonstrate improvement [3], despite encouraging data from a pilot open-label study such as this one. Furthermore, despite promising data from two small RCTs, a French phase IIb study of the anti-CD20 monoclonal antibody rituximab, targeting $\mathrm{B}$ cells, did not meet its primary outcome, despite significant beneficial effects on fatigue [4]. The reasons for this latter discrepancy are unclear but include methodological issues related to patient selection and outcome measures as well as those relating to target selection such as co-depletion of regulatory B cells and potential protection of pathogenic B cells in tissue niches. Some of these issues may be clarified by a UK study due to report later this year (http://public.ukcrn.org.uk/ search/StudyDetail.aspx?StudyID=9809). However, alongside $\mathrm{B}$ cells, there is evidence of an important pathogenic role for T cells, epithelial cells, natural killer (NK) cells, and type I and II interferons (IFN $\alpha / \beta$ and IFN $\gamma$, respectively). Analysis of minor salivary glands (MSGs) from an earlier open-label study of rituximab pointed to baseline differences in gene expression between responders and non- 
responders relating to B-cell and IFN pathways [5]. This suggests the tantalising possibility that patients may be stratified according to dominant pathogenic processes, and it is in regard to this that the study by Seror et al. is of greatest interest.

The authors studied peripheral blood lymphocyte subsets and MSGs at weeks 0 and 28 . The only findings associated with systemic response to belimumab were a lower percentage and number of peripheral NK cells and a smaller NK cell infiltrate around lymphocytic foci in the MSGs. Furthermore, the blood NK cell number rose in non-responders but not in responders at week 28. A role for NK cells in pSS is supported by a genetic susceptibility association with the NCR3 locus, encoding the NK-specific activating receptor NKp30 [6]. This polymorphism is associated with greater IFNY expression by NK cells. NK cells also enhance production of dendritic cell interleukin12 (IL-12), which is a key differentiation factor for $\mathrm{T}$ helper 1 (Th1) cells, themselves a major source of IFN $\gamma$ [7]. The data reported by Seror et al. might support the proposal of two dominant pathogenic axes, type I IFN/B cells and IFN $\gamma /$ IL- 12 . However, it should be emphasised that there is crosstalk between these two axes and they are not discrete. IFN $\gamma$ as well as type I IFN can drive BAFF expression [7], and B cells can produce IFN $\gamma$. Recent data have also suggested that a high MSG IFN $\gamma$, rather than IFN $\alpha$, signature is associated with lymphoma development [8]. Both NK cells and IFNY have been associated with the focus score [6,9], so it is also possible that NK cell infiltration may simply be associated with severity. Although the authors report a fall in the lymphocytic focus score (preferred over the Chisholm and Mason criteria [10]), this did not reach statistical significance, and they did not report whether baseline focus score correlated with NK infiltration or whether change in focus score was associated with response. This may require a larger sample size or a theoretically more sensitive measure such as focus score area [10]. Furthermore, it is not clear from the limited published data available how well NK cell number would function as a predictive biomarker in the clinic. Nevertheless, these exciting findings point to a need for stratification in pSS and hint at an exciting future of personalised medicine in pSS.

\footnotetext{
Abbreviations

BAFF: B-cell activating factor; BELISS: Efficacy and Safety of Belimumab in Subjects With Primary Sjögren's Syndrome; CD: Cluster of differentiation; IFN: Interferon; IL: Interleukin; MSG: Minor salivary gland; NK: Natural killer; pSS: Primary Sjögren's syndrome; RCT: Randomized controlled trial.
}

\section{Competing interests}

In the past year, SJB has consulted for Eli Lilly and Company (Indianapolis, IN, USA), Takeda Pharmaceuticals (Osaka, Japan), UCB (Brussels, Belgium), Novartis (Basel, Switzerland), Glenmark (Maharashtra, India), Celgene (Summit, NJ, USA), Medlmmune (Gaithersburg, MD, USA), and GlaxoSmithKline
(Brentford, UK) and is in receipt of an Arthritis Research UK grant to which Roche Pharmaceuticals (Basel, Switzerland) is contributing rituximab without charge. BAF has consulted for Medlmmune, Takeda Pharmaceuticals, and Novartis.

\section{Authors' contributions}

SJB and BAF contributed equally to the writing and revising of the manuscript and approved the final manuscript.

Published online: 07 December 2015

\section{References}

1. Seror R, Nocturne G, Lazure T, Hendel-Chavez H, Desmoulins F, Belkhir R, et al. Low numbers of blood and salivary natural killer cells are associated with a better response to belimumab in primary Sjogren's syndrome: results of the BELISS study. Arthritis Res Ther. 2015;17:241.

2. Mariette X, Seror R, Quartuccio L, Baron G, Salvin S, Fabris M, et al. Efficacy and safety of belimumab in primary Sjögren's syndrome: results of the BELISS open-label phase II study. Ann Rheum Dis. 2015;74:526-31.

3. Mariette X, Ravaud P, Steinfeld S, Baron G, Goetz J, Hachulla E, et al. Inefficacy of infliximab in primary Sjögren's syndrome: results of the randomized, controlled Trial of Remicade in Primary Sjögren's Syndrome (TRIPSS). Arthritis Rheum. 2004;50:1270-6.

4. Devauchelle-Pensec V, Mariette X, Jousse-Joulin S, Berthelot JM, Perdriger A, Puéchal $X$, et al. Treatment of primary Sjögren syndrome with rituximab: a randomized trial. Ann Intern Med. 2014;160:233-42.

5. Devauchelle-Pensec V, Cagnard N, Pers JO, Youinou P, Saraux A, Chiocchia G. Gene expression profile in the salivary glands of primary Sjögren's syndrome patients before and after treatment with rituximab. Arthritis Rheum. 2010;62:2262-71.

6. Rusakiewicz S, Nocturne G, Lazure T, Semeraro M, Flament C, Caillat-Zucman $S$, et al. NCR3/NKp30 contributes to pathogenesis in primary Sjogren's syndrome. Sci Transl Med. 2013;5:195ra96.

7. Nocturne G, Mariette X. Advances in understanding the pathogenesis of primary Sjögren's syndrome. Nat Rev Rheumatol. 2013;9:544-56.

8. Nezos A, Gravani F, Tassidou A, Kapsogeorgou EK, Voulgarelis M, Koutsilieris $M$, et al. Type I and II interferon signatures in Sjogren's syndrome pathogenesis: contributions in distinct clinical phenotypes and Sjogren's related lymphomagenesis. J Autoimmun. 2015;63:47-58.

9. Hall JC, Baer AN, Shah AA, Criswell LA, Shiboski CH, Rosen A, et al. Molecular subsetting of interferon pathways in Sjogren's syndrome. Arthritis Rheumatol. 2015:67:2437-46.

10. Fisher BA, Brown RM, Bowman SJ, Barone F. A review of salivary gland histopathology in primary Sjögren's syndrome with a focus on its potential as a clinical trials biomarker. Ann Rheum Dis. 2015;74:1645-50. 